\title{
Cervical cytology screening in a sexually transmitted diseases clinic for the first time in Sri Lanka
}

\author{
IYANTHIMALA ABEYEWICKREME \\ From the Central Venereal Diseases Clinic, Colombo, Sri Lanka
}

SUMMARY A prospective study of cervical cytology was carried out on 350 consecutive female patients attending the central venereal diseases clinic (CVDC) in Colombo, Sri Lanka. The main objective was to assess the proportion of abnormal cervical smears to emphasise the need to introduce routine cervical cytology screening in the sexually transmitted diseases (STD) clinics in Sri Lanka. Data about each woman's age, sexual history, method of contraception, number of pregnancies, genital infections, and previous cervical smears were collected to compare the findings in patients with normal smears with findings in those with abnormal smears. Smears reported as showing koilocytic atypia, dyskaryosis, carcinoma in situ, or invasive carcinoma were considered to be abnormal.

Forty seven (13.4\%) women in the study sample had abnormal smears, and 32 of these were aged under 35. None of the 350 patients had had a cervical smear taken previously. Women who had had five or more pregnancies, compared with those who had had four or fewer pregnancies, and women with trichomoniasis, compared with no genital infection, had significantly higher incidences of abnormal than normal smears. Higher proportions of abnormal than normal smears were also found in women whose sexual partners had been surgically sterilised. These findings suggest a serious need for cervical cytology screening in STD clinics.

Squamous cell neoplasia of the uterine cervix is the cancer that most commonly affects women in the developing countries.' Worldwide, cervical cancer is the second most common cancer in women, breast cancer being the commonest.

Carcinoma of the cervix is now considered to be a sexually transmitted disease (STD). Recent research indicates that a sexually transmissible virus, the human papillomavirus (HPV) is probably the oncogenic agent. ${ }^{2-5}$ The oral contraceptive pill ${ }^{6}$ and smoking ${ }^{7}$ are two other non-sexually transmitted possible cofactors. In 1842 Rigoni-Stern noted that cervical cancer was rare in nuns. ${ }^{8}$ Since then many epidemiological studies have confirmed that the risk factors associated with carcinoma of the cervix are related mostly to coitus. ${ }^{9-11}$ Women attending STD clinics commonly share two of the major risk factors, early age at first coitus and multiple sexual partners, which places them at high risk for developing cervical cancer.

Address for reprints: Dr I Abeyewickreme, Central Venereal Diseases Clinic, PO Box 567, De Saram Place, Colombo 10, Sri Lanka

Accepted for publication 21 September 1988
Cervical cytology screening is a well established procedure that is carried out routinely in STD clinics in the developed countries, where it has been shown to be effective in reducing mortality from and incidence of the disease. ${ }^{12-14}$ Although cervical cancer screening of patients attending STD clinics is carried out in some developing countries, Sri Lanka is not one of them. There is also no national cervical cancer screening programme on the island. Taking all these factors in to consideration, I carried out a prospective study of cervical cytology screening in women attending the central venereal diseases clinic (CVDC) in Colombo. The objectives of the study were (1) to assess the proportion of cervical smears that show abnormal cytology results, and (2) to compare data about age, sexual history, contraceptive methods, number of pregnancies, genital infections, and previous cervical smears in patients with normal smears compared with those with abnormal smears.

\section{Patients and methods}

I screened 350 consecutive female patients attending the CVDC, Colombo from 2 July to 30 September 
1986. New patients as well as those attending for follow up were included because time and financial resources available for carrying out the study were limited.

Data about each patient's age, date of last menstruation, age at first coitus, number of sexual partners, number of pregnancies, method of contraception, and previous cervical smears were noted on a structured precoded questionnaire before she was examined. A cervical smear was taken from the squamocolumnar junction with an Ayre's spatula, spread on a glass slide, and fixed immediately in a solution of $95 \%$ alcohol. The smears were sent to the pathology laboratory at the Faculty of Medicine of the University of Colombo for staining and examination. (Routine cervical swabs were taken after the cytology smear.) Abnormal cytology results were reported using the terms koilocytic atypia, dyskaryosis (mild, moderate, or severe), carcinoma in situ, or invasive carcinoma. For the purpose of this study, smears reported as showing squamous metaplasia or inflammatory change (due to trichomoniasis, candidiasis, genital herpes, or gonorrhoea) were considered to be normal. Each patient with an abnormal smear had a repeat smear taken four weeks later.

\section{Results}

Of cervical smears taken from 362 patients who attended the CVDC during the period under study, 12 (3.3\%) had to be excluded because of clerical errors (mislabelling of slides and cytology request forms). Of the remaining $350,47(13.4 \%)$ had abnormal cytology results (table 1). Mild and moderate dyskaryosis accounted for most $(36 / 47,76.6 \%)$ of the abnormal smears. One patient's smear showed carcinoma in situ changes. None of the 350 women had had a previous cervical smear.

The mean age of the 350 women was 29 (range 15 to 62) years. The mean age of the 47 with abnormal smears was 32 and that of the 303 with normal smears was 29 . Table 2 shows the ages of the 47 women with
Table 1 Results of cervical smears from 350 patients

\begin{tabular}{lrl}
\hline Cytology results & \multicolumn{2}{c}{ No (\%) with given result } \\
\hline Koilocytic atypia & 5 & $(1 \cdot 4)$ \\
Mild dyskaryosis & 18 & $(5 \cdot 1)$ \\
Moderate dyskaryosis & 18 & $(5 \cdot 1)$ \\
Severe dyskaryosis & 5 & $(1 \cdot 4)$ \\
Carcinoma in situ & 1 & $(0 \cdot 3)$ \\
Inflammatory cells & 126 & $(36 \cdot 0)$ \\
Normal cervical cells & 177 & $(50 \cdot 6)$ \\
\hline
\end{tabular}

abnormal cytology results according to the type of abnormality.

The mean (SEM) age at first coitus in the women with normal smears was $19.7(0.26)$ compared with $18.7(0.66)$ in those with abnormal smears, which was not a significant difference.

Oocasional difficulties arose in obtaining accurate estimates of the numbers of sexual partners of women who were engaged in prostitution. In those instances approximate figures were taken. Most women, however, $(68 \%(32 / 47)$ of those with abnormal smears and $65 \%(198 / 303)$ of those with normal smears), had had only one sexual partner. I grouped the women according to the numbers of their sexual partners $(1,2$, $3-100,101-500,501-1000$, or more than 1001) to compare those with normal smears and those with abnormal smears, but no significant difference could be found.

Of the 350 women in the study, 100 voluntarily stated that they were engaged in prostitution. Of these, 87 had normal and 13 abnormal smears. Ten of the prostitutes were also addicted to heroin.

Table 3 shows the smear statuses of patients according to their numbers of pregnancies. Women who had had five or more pregnancies had a significantly ( $p<$ $0.01)$ higher proportion $(27.6 \%, 16 / 58)$ of abnormal smears than did those who had had four or fewer pregnancies $(10.6 \%, 31 / 292)$.

Surgical sterilisation (by tubal ligation) of women was the most common method of contraception found in the 350 women. The youngest patient with tubal ligation was aged 19 and engaged in prostitution. In

Table 2 Ages of 47 patients with abnormal cytology results according to type of abnormality

\begin{tabular}{|c|c|c|c|c|c|}
\hline \multirow[b]{2}{*}{ Age (years) } & \multicolumn{4}{|c|}{ Type of abnormality } & \multirow[b]{2}{*}{ Total } \\
\hline & $\begin{array}{l}\text { Koilocytic } \\
\text { atypia }\end{array}$ & $\begin{array}{l}\text { Mild } \\
\text { dyskaryosis }\end{array}$ & $\begin{array}{l}\text { Moderate } \\
\text { dyskaryosis }\end{array}$ & $\begin{array}{l}\text { Severe } \\
\text { dyskaryosis }\end{array}$ & \\
\hline $\begin{array}{l}15-19 \\
20-24 \\
25-29 \\
30-34 \\
35 \text { and over }\end{array}$ & $\begin{array}{l}1 \\
1 \\
3 \\
0 \\
0\end{array}$ & $\begin{array}{l}0 \\
4 \\
5 \\
4 \\
5\end{array}$ & $\begin{array}{l}1 \\
0 \\
4 \\
5 \\
8\end{array}$ & $\begin{array}{l}0 \\
0 \\
2 \\
2 \\
2^{*}\end{array}$ & $\begin{array}{r}2 \\
5 \\
14 \\
11 \\
15\end{array}$ \\
\hline Total & 5 & 18 & 18 & 6 & 47 \\
\hline
\end{tabular}

*Includes one patient with carcinoma in situ changes. 
Table 3 Smear statuses of 350 patients according to numbers of pregnancies

\begin{tabular}{lrrl}
\hline $\begin{array}{l}\text { No of } \\
\text { pregnancies }\end{array}$ & No & $\begin{array}{l}\text { Normal } \\
\text { smears }\end{array}$ & $\begin{array}{l}\text { Abnormal } \\
\text { smears }\end{array}$ \\
\hline $\begin{array}{l}4 \text { or fewer } \\
5 \text { or more }\end{array}$ & 292 & $261(89 \cdot 4)$ & $31(10 \cdot 6)$ \\
\hline
\end{tabular}

*Student's $t$ test, $t=2.76 ; 2 \mathrm{df} ; \mathrm{p}<0.01$.

fact, $72 \%$ of the prostitutes were permanently sterilised. Table 4 shows the smear status of each of the 350 patients according to her method of contraception. Women whose sexual partners had had a vasectomy had a higher proportion of abnormal $(8.5 \%, 4 / 47)$ than normal $(2 \cdot 3 \%, 7 / 303)$ smears.

Table 5 compares women with normal and those with abnormal smears according to their diagnoses. The incidence of genital herpes and genital wart virus (human papillomavirus (HPV) infection did not differ appreciably between patients with normal smears and those with abnormal smears. Patients who had koilocytic atypia did not have any visible genital warts. Of patients with trichomoniasis, however, $11.3 \%$ more had abnormal than normal smears compared with $\mathbf{9 . 2} \%$ more normal than abnormal smears in

Table 4 Smear statuses of 350 patients according to their methods of contraception

\begin{tabular}{lrr}
\hline & \multicolumn{2}{l}{ No (\%) with: } \\
\cline { 2 - 3 } Contraceptive method & $\begin{array}{l}\text { Normal } \\
\text { smears } \\
(n=303)\end{array}$ & $\begin{array}{l}\text { Abnormal } \\
\text { smears } \\
(n=47)\end{array}$ \\
\hline Natural & $8(2 \cdot 6)$ & 0 \\
Oral contraception & $12(4 \cdot 0)$ & $3(6 \cdot 4)$ \\
Intrauterine device & $7(2 \cdot 3)$ & 0 \\
Medroxyprogesterone acetate & $11(3.6)$ & $3(6 \cdot 4)$ \\
Condom & $12(4 \cdot 0)$ & $1(2 \cdot 1)$ \\
Tubal ligation & $87(28 \cdot 7)$ & $16(34 \cdot 0)$ \\
Vasectomy of partner & $7(2 \cdot 3)$ & $4(8 \cdot 5)$ \\
None & $135(44 \cdot 6)$ & $15(31 \cdot 9)$ \\
Pregnant & $24(7.9)$ & $5(10 \cdot 6)$ \\
\hline
\end{tabular}

Table 5 Smear statuses of 350 patients according to the infection diagnosed

\begin{tabular}{|c|c|c|}
\hline $\begin{array}{l}\text { Infection } \\
\text { diagnosed }\end{array}$ & $\begin{array}{l}\text { No (\%) with: } \\
\text { Normal smears } \\
(n=303)\end{array}$ & $\begin{array}{l}\text { Abnormal smears } \\
(n=47)\end{array}$ \\
\hline $\begin{array}{l}\text { Genital warts } \\
\text { Genital herpes } \\
\text { Syphilis } \\
\text { Gonorrhoea } \\
\text { NSGI } \\
\text { Candidiasis } \\
\text { Trichomoniasis } \\
\text { Scabies } \\
\text { No infection }\end{array}$ & $\begin{aligned} 14 & (4 \cdot 6) \\
15 & (5 \cdot 00) \\
22 & (7 \cdot 3) \\
30 & (9 \cdot 9) \\
82 & (27 \cdot 1) \\
28 & (9 \cdot 2) \\
43 & (14 \cdot 2) \\
9 & (3 \cdot 0) \\
60 & (19 \cdot 8)\end{aligned}$ & $\begin{array}{rr}2 & (4 \cdot 3) \\
2 & (4 \cdot 3) \\
3 & (6 \cdot 4) \\
5 & (10 \cdot 6) \\
14 & (29 \cdot 8) \\
2 & (4 \cdot 3) \\
12 & (25 \cdot 5) \\
2 & (4 \cdot 3) \\
5 & (10 \cdot 6)\end{array}$ \\
\hline
\end{tabular}

NSGI = non-specific genital infection.

*Student's $t$ test, $t=2.177 ; 2 \mathrm{df} ; \mathrm{p}<0.01$ (difference between normal and abnormal smears in patients with trichomoniasis and in those with no infection). patients with no infection, a significant $(\mathrm{p}<0.01)$ difference. The infection most commonly diagnosed was non-specific genital infection.

\section{Discussion}

Primary prevention is the ideal strategy to control cervical cancer. As it has easily recognisable early stages (pre-invasive disease stages), cervical cancer should theoretically be possible to control by exfoliative cervical cytology, a simple, sensitive, inexpensive and a non-invasive method, which makes detecting preinvasive disease relatively easy.

Cervical cancer is still difficult to control, however, as women at high risk of contracting it are not usually amenable to being screened. Women attending STD clinics belong to the high risk category, and screening this group of the population should be effective in terms of numbers detected and cost. In this study $13.4 \%$ of smears were abnormal, which confirms that patients attending STD clinics are at high risk of developing cervical neoplasia. This figure does not represent the true picture, however, as fewer than one third of people with STD seek treatment at STD clinics in Sri Lanka. ${ }^{15}$ Most seek treatment privately, and the exact numbers of private patients are not known. The figure of $13.4 \%$, however, reflects a trend, which can be used in identifying the magnitude of the problem.

In this study, of the 303 normal smears, 126 were reported as showing inflammatory change (table 1). Toon et al recommended that patients with inflammatory changes should be investigated with care and be paid the same amount of attention as those with dyskaryotic smears. ${ }^{16}$ They need to be tested for specific diseases, such as trichomoniasis, candidiasis, gonorrhoea, and HSV infection, and their smears should be repeated at regular intervals because evidence shows that up to one fifth of patients with recurrent inflammatory smears may have underlying cervical intraepithelial neoplasia. More than a third of the patients in this study had inflammatory smears, which is another indication to introduce routine cytology screening in STD clinics.

Relatively few reports about cervical cytology screening in STD clinics have been published. ${ }^{17-21}$ In a study from New Zealand, the incidence of abnormal smears was found to be $14.6 \% .^{22}$ The incidence of dysplasia and carcinoma in situ in that study was $6.6 \%$ (33/500). Briggs et al of Seattle, United States of America, also reported an incidence of $11.4 \%$ for dysplasia and carcinoma. ${ }^{23}$

The high proportion of cervical dyskaryosis in patients attending STD clinics was consistent with the view that squamous cell carcinoma of the cervix is an STD related to first coitus in early life, promiscuity, and prostitution. In this study, the mean age at first 
coitus in those with abnormal smears was 18.7 years, which was higher than the corresponding ages in the New Zealand ${ }^{22}$ and American ${ }^{23}$ studies. That may be due to the sociocultural background in Sri Lanka, where arranged marriages are still prevalent and a Sri Lankan woman's first experience of coitus is usually within marriage. Her western counterpart is free from such cultural ties and tends to experience sex before marriage and at an earlier age.

A previous study has shown that prostitutes are at high risk of developing cervical carcinoma and therefore need to be screened regularly. ${ }^{24}$ Of the 100 prostitutes in this study, 10 were addicted to heroin. Without heroin they could not carry on with their profession, and without work they could not purchase heroin, thus creating a vicious circle from which there was no escape. The CVDC in Colombo receives many referrals from magistrates to investigate prostitutes and vagrants, who account for about $23 \%$ of the new patients attending the CVDC's clinic for women each year. This is yet another factor in favour of introducing cervical cytology screening to the STD clinics in Sri Lanka.

Patients who had had five or more pregnancies had a significantly higher proportion of abnormal smears than those who had had four or fewer pregnancies. This finding confirms those of a previous epidemiological study," which showed that the prevalence of cervical cancer was found to increase steadily with increasing numbers of pregnancies.

Although oral contraceptives have been shown to have certain effects on the development of cervical carcinoma, ${ }^{6}$ the present study did not show any correlation. Few women, however (less than 5\%) in the study group used oral contraceptives. The most commonly practiced method of contraception was tubal ligation, possibly to a large extent because the government of Sri Lanka offers a financial incentive to those undergoing voluntary surgical sterilisation. Another factor to be considered is that the study group contained a high percentage of prostitutes, who resort to a permanent method more often for obvious reasons. A higher percentage $(8.5 \%)$ of abnormal than normal $(2.3 \%)$ smears was found in women whose sexual partners had had a vasectomy. The men who were permanently sterilised may have been more promiscuous, which would have rendered their female sexual partners vulnerable to infection with sexually transmitted oncogenic agents. That is a subject that needs further investigation, as vasectomy is as popular as tubal ligation as a contraceptive method in Sri Lanka.

Many reports support the view that HPV and, to a lesser extent, herpes simplex virus play an important part in the aetiology of cervical neoplasia..$^{2-525-27}$ Surprisingly though, no significant difference could be found between patients with abnormal smears and those with normal smears in women with genital herpes or genital wart virus infections in this study. Genital warts are not often seen in women with STD in Sri Lanka. During 1986 only $2 \%$ of new female patients attending the CVDC had genital warts. HPV can, however, infect the cervix without condylomata being present macroscopically. ${ }^{2829}$ In this study, none of the five women who showed koilocytic atypia in their cervical smears had visible genital warts. Perhaps HPV infection may present in this way in women in this country. It is unfortunate that colposcopy is not available in our STD or gynaecology clinics, as colposcopically directed tissue sampling of atypical areas of the uterine cervix would undoubtedly give valuable information in addition to the cervical smear results.

At the CVDC in Colombo, vaginal trichomoniasis was the second most common STD diagnosed in female patients. It was very common in the prostitutes, either alone or in combination with gonorrhoea. Most episodes of trichomoniasis are due to repeat infections, as it is almost impossible to get the sexual partners of infected patients to attend for investigation and concurrent treatment. Trichomonads have been suggested as a possible carcinogen associated with coitus ${ }^{30}$ and in this study significantly $(p<0.01)$ more abnormal than normal smears were seen in patients with this infection than in those with no genital infection.

The high yield of cervical smear abnormalities in patients attending an STD clinic as shown by the findings in this study indicates an urgent need for cervical cytology screening in these clinics in Sri Lanka. As the country is a developing one, with limited financial resources, a screening service designed to fit in with existing medical facilities such as STD, antenatal, and family planning clinics would be more cost effective than developing a separate vertical screening programme.

I thank Dr P U Thelisinghe, Pathologist, Faculty of Medicine, University of Colombo, for performing cytological examinations and the staff of the CVDC, Colombo, for their co-operation in carrying out the study.

This report is based on a study carried out and submitted in the form of a dissertation (unpublished) by the author for the masters degree in March 1987.

\section{References}

1 Parking DM, Stjernsward J, Muir CS. Estimates of the world wide frequency of twelve major cancers. Bull WHO 1984;62:163-82.

2 Shah KH, Lewis MG, Jensen AB, Kurman RJ, Lancaster WD. Papillomavirus and cervical dysplasia. Lancet 1980;ii:1190.

3 zur Hausen H, de Villiers EM, Gissman L. Papillomavirus 
infections and human genital cancer. Gynecol Oncol 1981;12 124-8.

4 Syrjanen KJ, Heinonen UM, Karuaniemi T. Cytologic evidence of the association of condylomatous lesions with dysplastic and neoplastic changes in the uterine cervix. Acta Cytol 1981;25: 17-22.

5 Boshart M, Gissman L, Ikenberg H, Kleinheinz A, Scheurlen W, zur Hausen H. A new type of papillomavirus DNA, its presence in genital cancer biopsies and in cell lines derived from cervical cancer. EMBO J 1984;3:1151-7.

6 Vessey MP, Lawless M, McPherson K, Yates D. Neoplasia of the cervix uteri and contraception: a possible adverse effect of the pill. Lancet 1983;ii:930-4.

7 Trevathan E, Layde P, Webster LA, Adams JB, Benigno BB, Ory $H$. Cigarette smoking and dysplasia and carcinoma in situ of the uterine cervix. JAMA 1983;250:499-502.

8 Rigoni-Stern D. Fatti statistici relativi alle mallattie cancerose. Giornale per servire al Progress e della Patologia e della Terapia 1842;2:507-17.

9 Martin CE. Marital and coital factors in cervical cancer. Am J Public Health 1967;57:803-14.

10 Rotkin ID. A comparison review of key epidemiologic studies in cervical cancer related to current searches for transmissible agents. Cancer Res 1973;33:1353-67.

11 Rotkin ID. Sexual characteristics of a cervical cancer population. Am J Public Health 1967;57:815-29.

12 Walton RJ. Cervical cancer screening programmes. The Walton report. Can Med Assoc J 1976;114:1003-33.

13 Hakama M. Trends in the incidence of cervical cancer in the Nordic countries. In: Magnus $\mathrm{K}$, ed. Trends in cancer incidence. Washington: Hemisphere, 1982:279-92.

14 Johannesson $G$, Geirsson G, Tulinis $H$. Trends in incidence in Iceland. In: Magnus K, ed. Trends in cancer incidence. Washington: Hemisphere, 1982:305-9.

15 Anonymous. Annual Health Bulletin, Sri Lanka. Colombo, Sri Lanka: Ministry of Health, Government Press, 1986:102.

16 Toon PG, Arrand JR, Wilson LP, Sharp DS. Human papillomavirus infection of the uterine cervix of women without cytological signs of neoplasia. Br Med J 1986;293:1261-4.

17 Nelson RB, Hilberg MD. The diagnosis of unsuspected cancer of the cervix. Journal of the National Cancer Institute
(Washington) 1951;11:1081-91.

18 Farrer CJ, Tatham PH. Screening for carcinoma of the uterine cervix in a VD clinic. British Journal of Venereal Diseases 1962;38:230-1.

19 Penderson AHB. Cytological screening for cancer in a venereal diseases programme. Public Health Rep 1964;79:112-8.

20 Lucas AJ, Williams DR. Cervical cytology of patients attending a venereal disease clinic. Journal of Obstetrics and Gynaecology of the British Commonwealth (London) 1967;74:104-10.

21 Alawattegama AB. Screening for cervical intraepithelial neoplasia and cancer in the Sheffield STD clinic. British Journal of Venereal Diseases 1984;60:117-20.

22 Lyttle H, Platts WM, MacLean AB. Pilot study of cervical cytology screening in a sexually transmitted diseases clinic. Genitourin Med 1985;61:330-4.

23 Briggs RM, Holmes KK, Kiviat N, Barker E, Eschenbach DA, DeJong R. High prevalence of cervical dysplasia in STD clinic patients warrants routine cytologic screening. Am J Public Health 1980;70:1212-4.

24 Moghissi KS, Mack HC, Porzack JP. Epidemiology of cervical cancer: study of a prison population. Am J Obstet Gynecol 1968; 100:607-12.

25 McDougall JK, Galloway DA, Fenoglio CM. Cervical carcinoma: detection of herpes simplex virus RNA in cells undergoing neoplastic change. Int J Cancer 1980;25:1-8.

26 Eglin RP, Sharp F, MacLean AB, MacNab JCM, Clements JB, Wilkie NM. Detection of RNA complementary to herpes simplex virus DNA in human cervical squamous cell neoplasms. Cancer Res 1981;41:3597-603.

27 zur Hausen H. Human genital cancer: synergism between two virus infections or synergism between a virus infection and initiating events? Lancet 1982;ii:1370-2.

28 Reid R, Laverty CR, Coppleson M, Israngkul W, Hills E. Noncondylomatous cervical wart virus infection. Obstet Gynecol 1980;55:476-83.

29 Meisels A, Roy M, Fortier M, et al. Human papillomavirus infection of the cervix: the atypical condyloma. Acta Cytol (Baltimore) 1981;25:7-16.

30 Thomas DB. An epidemiological study of carcinoma in situ and squamous dysplasia of the uterine cervix. Am J Epidemiol 1973; 98:10-28. 